\title{
Strategi Pendampingan Sebagai Upaya Pemenuhan Hak Anak Korban Kekerasan di Kota Pasuruan
}

\author{
Monica Widyaswari \\ Pendidikan Luar Sekolah, Universitas Negeri Malang \\ Email: mwidyaswari@gmail.com \\ Hardika \\ Universitas Negeri Malang \\ Email: $\underline{\text { hardika.fip@um.ac.id }}$ \\ Umi Dayati \\ Universitas Negeri Malang \\ Email: umidayati.fip@um.ac.id
}

\begin{abstract}
Abstrak
Tujuan penelitian ini adalah mengkaji strategi pendampingan anak korban kekerasan di Kota Pasuruan. Upaya Kota Pasuruan dalam mengakomodir hak-hak anak korban kekerasan secara medis, yuridis, dan psikologis. Penelitian menggunakan pendekatan kualitatif dengan jenis penelitian studi kasus. Informan dalam penelitian ini meliputi DP3AKB dan P2TP2A selaku lembaga pemerintahan yang melakukan pendampingan dan LPA selaku lembaga nonpemerintahan. Prosedur pengumpulan data dilakukan melalui wawancara mendalam, observasi, dan studi dokumen. Analisis data pada penelitian ini menggunakan model Spradley. Hasil penelitian menunjukkan bahwa secara umum Kota Pasuruan berkomitmen untuk memenuhi hak anak korban kekerasan melalui lima strategi yang mencakup psikologis, medis, dan yuridis diantaranya: (1) sosialisasi penguatan pengasuhan kepada keluarga; (2) penyediaan pendamping anak secar terlatih; (3) penguatan dukungan peraturan dan kebijakan perlindungan anak; (4) penyediaan layanan ramah anak bagi korban kekerasan; dan (5) pemetaan kasus kekerasan pada anak. Kota Pasuruan melalui lembaga yang bertugas juga menyediakan layanan preventif yang mencakup: peningkatan keterampilan pengasuhan, penyediaan layanan ramah anak untuk korban kekerasan, dan diseminasi informasi perlindungan anak. Sedangkan layanan represif meliputi: pengajuan laporan pengaduan tindak kekerasan, identifikasi kasus sesuai layanan yang dikehendaki, upaya penanganan dan penyelesaian kasus, serta monitoring dan evaluasi.
\end{abstract}

Kata Kunci: Pendampingan, Hak Anak, Korban Kekerasan

\begin{abstract}
The purpose of this study was to examine strategies for assisting children victims of violence in Pasuruan City. Pasuruan City's efforts in accommodating the rights of child victims of violence medically, juridically, and psychologically. This research used a qualitative approach with the type of case study research. Informants in this study include DP3AKB and P2TP2A as government agencies that provide assistance and LPA as non-governmental organizations. The data collection procedure was carried out through in-depth interviews, observation, and study of document. Data analysis in this study used the Spradley model. The results showed that, in general, Pasuruan City is committed to fulfilling the rights of child victims of violence through five strategies covering psychological, medical, and juridical, including (1) socialization of strengthening care to families; (2) providing trained child companions; (3) strengthening support for child protection regulations and policies; (4) providing child-friendly services for victims of violence; and (5) mapping cases of violence against children. Pasuruan City, through the agency in charge, also provides preventive services that include: improving parenting skills, providing child-friendly services for victims of violence, and disseminating information on child protection. Meanwhile, repressive services include filing reports of complaints of violence, identifying cases according to services, efforts to handle and resolve cases, and monitoring and evaluation.
\end{abstract}

Keywords: Mentoring, The Rights of Child, Victims of Violence 


\section{PENDAHULUAN}

Dalam kehidupan sehari-hari terdapat berbagai kasus kekerasan yang melibatkan anak. Kekerasan terhadap anak dinilai semakin tinggi, terlebih seperti saat ini kekerasan tidak hanya dilakukan oleh orang dewasa namun juga menjerat anak sebagai pelakunya. Maraknya kekerasan terhadap anak tentu tidak sejalan dengan nilai-nilai agama maupun kemanusiaan atau kesusilaan serta peraturan perundangundangan yang berlaku.

Merujuk pada data dari sistem pelaporan SIMFONI-PPA selama periode 2015-2016, jumlah kasus kekerasan mengalami kenaikan sebanyak tiga kali lipat. Pada tahun 2015 tercatat sebanyak 1975 kasus dan meningkat menjadi 6.820 kasus di tahun 2016. Jumlah ini sejalan dengan pengaduan anak yang diterima oleh Komisi Perlindungan Anak Indonesia (KPAI) dalam periode yang sama yaitu dari 4.309 kasus menjadi 4.620 kasus. Meskipun dinilai fluktuasi selama periode 2011-2016 jumlah kasus pengaduan anak cenderung meningkat. Dalam hal ini terlihat apabila jumlah yang dicatat KPAI pada tahun 2016 jauh lebih rendah. Kekerasan terhadap anak seperti halnya fenomena gunung es, hanya sebagian kecil kasus yang dilaporkan dan sebenarnya jumlah kasus tergolong sangat tinggi (Kementerian Pemberdayaan Perempuan dan Perlindungan Anak Republik Indonesia, 2017). Berdasarkan jenis kasus, tindak asusila menempati posisi teratas diikuti dengan kekerasan psikis dan fisik. Pada tahun 2016, jumlah kasus tindak asusila terhadap anak mencapai $35 \%$ dari total jumlah kasus kekerasan terhadap anak, sementara kekerasan fisik dan psikis berkisar 28 dan $23 \%$ dari total kasus. Jenis kekerasan lain seperti pengabaian atau penelantaran dan kesalahan pengasuhan sekitar 7\%. Ditelusuri menurut jenis kelamin, kasus kekerasan terhadap anak lebih rentan terjadi pada anak perempuan.

Kekerasan terhadap anak atau child against violence adalah segala bentuk tindakan yang dilakukan oleh orang lain kepada anak sehingga menghambat kelangsungan hidup dan tumbuh kembangnya akibat kerugian secara fisik, psikologis, seksual, ataupun finansial yang ditimbulkan (Callaghan dkk., 2017). Kekerasan anak terbagi atas empat jenis yaitu fisik (physical), mental atau psikis (psychological), tindak asusila (sexual), dan pengabaian (deprivation) (Lourenco dkk., 2013).

Adanya praktik kekerasan anak termasuk dalam salah satu bentuk pelanggaran terhadap hak asasi manusia (HAM). Adanya permasalahan sosial terkait kekerasan pada anak disebabkan oleh beberapa faktor, salah satunya karena minim atau tidak adanya kontrol sosial dari lingkungan sosial terhadap anak, baik dari keluarga, sekolah, maupun masyarakat.

Kota Pasuruan merupakan salah satu daerah yang telah memperoleh predikat Kota Layak Anak (KLA) tingkat pratama. Namun, daerah tersebut masih mendapat perhatian khusus terkait aspek perlindungan khusus untuk kekerasan anak. Hal ini dikarenakan adanya kasus kekerasan anak yang dinilai masih rentan terjadi, terlebih dengan melibatkan anak sebagai korban. Rerata jenis kekerasan anak di Kota Pasuruan berkaitan dengan fisik, mental atau psikis, tindak asusila, pelarian anak, serta pengabaian dan kesalahan dalam pengasuhan. Berdasarkan data dari Pusat Pelayanan Terpadu Pemberdayaan Perempuan dan Anak (P2TP2A), tahun 2016 terdapat 43 anak korban kekerasan dan berhasil turun menjadi 40 korban pada tahun 2017. Sementara tahun 2018 dihadapkan dengan 39 korban.

Berdasarkan Undang-undang Nomor 35 Tahun 2014 tentang Perlindungan Anak pasal 1, perlindungan anak diartikan sebagai "segala kegiatan untuk menjamin dan melindungi anak dan hak-haknya agar dapat hidup, tumbuh, berkembang, dan berpartisipasi secara optimal sesuai dengan harkat dan martabat kemanusiaan, serta mendapat perlindungan dari kekerasan dan diskriminasi”. Dalam hal ini 
ditekankan bahwa anak-anak berhak memperoleh pengasuhan dan pemeliharaan sebagaimana yang menjadi haknya secara layak pada aspek kesehatan, pendidikan, sandang dan pangan, mental, emosi, serta agama.

Kota Pasuruan berusaha komitmen untuk melakukan strategi perlindungan anak guna menekan persentase kasus per tahunnya. Strategi tersebut diakomodir oleh Kota Pasuruan melalui layanan yang telah dikembangkan oleh berbagai pihak, baik dari sektor pemerintahan dan nonpemerintahan. Upaya perlindungan digiatkan dalam rangka menjamin hak anak agar tetap mendapatkan akses tumbuh kembang dengan baik. Akses tumbuh kembang anak dilakukan dengan mengutamakan prinsip the best interest of the child tanpa diskriminasi sehingga tidak menimbulkan dampak negatif lainnya.

Anak korban kekerasan tentu akan mengalami dampak negatif atau trauma dari peristiwa yang diketahui dan dialaminya. Selain itu, anak yang mengalami kekerasan juga dapat berpotensi untuk menjadi pelaku tindak kekerasan ketika dewasa (Hasanah \& Raharjo, 2016a). Oleh karena itu diperlukan strategi pendampingan yang baik melalui kerja sama lingkungan di sekitar anak. Dalam hal ini mencakup orangtua atau wali, keluarga, pemerintah bahkan negara.

Anak korban kekerasan memerlukan perhatian seluruh pihak. Hal ini dikarenakan adanya dampak trauma yang akan dihadapi anak, baik sebagai korban maupun pelaku. Dalam beberapa kasus, pelaku dari tindak kekerasan pada anak bermula dari masa kecilnya yang merupakan korban. Pendampingan anak korban kekerasan perlu dilakukan secara bersama-sama melalui koordinasi antar insitusi agar pelayanan yang diberikan lebih komprehensif sebagaimana dalam Undang-undang Republik Indonesia Nomor 35 Tahun 2014 tentang Perlindungan Anak pasal 20.

Pendampingan adalah bentuk interaksi secara dinamis kepada kelompok minoritas dalam menghadapi situasi darurat melalui kiat seperti (a) merancang program demi perbaikan kehidupan; (b) memobilisasi sumber daya; (c) memecahkan masalah sosial; (d) memberikan akses dalam rangka memenuhi kebutuhan; dan (e) menjalin kerja sama dengan pihak-pihak yang relevan dengan mengusung konsep pemberdayaan (Graha, 2009). Pada pendampingan anak korban kekerasan diperlukan pemenuhan hak secara psikologis, medis, dan yuridis. Adanya pendampingan tersebut tidak diperoleh dari layanan pendidikan formal, melainkan dijangkau oleh kegiatan pendidikan nonformal melalui dukungan sosial. Layanan tersebut berguna untuk membantu anak dalam menyelesaikan kasus dan meningkatkan self-esteem pasca dihadapkan oleh suatu situasi darurat melalui kegiatan atau layanan ramah anak.

Berdasarkan latar belakang di atas, tujuan penelitian ini adalah untuk mengkaji strategi pendampingan sebagai upaya pemenuhan hak anak korban kekerasan yang dilakukan oleh Kota Pasuruan. Dari hasil kajian tersebut diketahui sinergitas antar pihak dalam melindungi anak korban kekerasan.

\section{METODE}

Penelitian ini merupakan penelitian studi kasus dengan pendekatan kualitatif. Penelitian dilakukan untuk mengetahui upaya pendampingan yang dilakukan oleh Kota Pasuruan sebagai upaya pemenuhan hak anak korban kekerasan berbasis kondisi alamiah yang terjadi di situasi sosial tersebut.

Kota Pasuruan merupakan salah satu daerah yang mengembangkan lingkungan ramah anak dan memperoleh predikat KLA tingkat pratama. Namun, masih mendapat perhatian khusus terkait perlindungan anak dari adanya kekerasan. Upaya perlindungan anak tersebut perlu ditingkatkan, mengingat kasus kekerasan anak di daerah tersebut masih rentan terjadi terlebih yang melibatkan anak sebagai korban. 
Pengumpulan data dilakukan dengan teknik observasi, studi dokumentasi, dan wawancara mendalam kepada informan kunci yaitu Dinas Pemberdayaan Perempuan, Perlindungan Anak, Pengendalian Penduduk dan Keluarga Berencana (DP3AKB) selaku leading sector. Selain itu dilakukan kepada Pusat Pelayanan Terpadu Pemberdayaan Perempuan dan Anak (P2TP2A) selaku lembaga pemerhati anak yang aktif dari pemerintahan. Sedangkan dari nonpemerintahan dilakukan kepada Lembaga Perlindungan Anak (LPA). Teknik penentuan informan pada penelitian ini didasarkan pada kriteria dengan mempertimbangkan peran informan dalam pelaksanaan pendampingan dan perlindungan anak korban kekerasan. Informasi yang diperoleh melalui multi teknik tersebut selanjutnya dianalisis. Berkenaan dengan analisis data, penelitian ini menggunakan teknik analisis data model Spradley melalui empat tahap yaitu analisis domain, taksonomi, komponensional, dan tema.

\section{HASIL}

\section{Gambaran Umum Kekerasan pada Anak}

Kota Pasuruan terbagi atas empat kecamatan yaitu Purworejo, Panggurejo, Bugul Kidul, dan Gadingrejo. Di Kota Pasuruan, terdapat beberapa jenis kasus kekerasan anak diantaranya secara fisik, psikis, tindak asusila, serta penelantaran dan kesalahan pengasuhan. Sementara sebagian diantaranya mencakup kasus perebutan hak asuh anak akibat kekerasan dalam rumah tangga (KDRT). Kondisi ini selaras dengan pembagian Lourenco et al. (2013) terkait bentuk kekerasan anak yang mencakup fisik (physical), psikis (psychological), tindak asusila (sexual), dan pengabaian (deprivation). Kekerasan anak rentan terjadi di lingkungan pendidikan dalam bentuk kekerasan fisik dan psikis berawal dari perundungan (bullying) antar teman. Hal ini sesuai dengan paparan Agustin, Saripah, \& Gustiana (2018) yang menyatakan bahwa sedikitnya $10-16 \%$ dalam seminggu siswa di Indonesia mendapat dan melaporkan kasus perundungan akibat cemoohan, pengucilan, pemukulan, tendangan, dan didorong.

Dari ragam kekerasan yang terjadi di Kota Pasuruan, jenis kekerasan fisik dan psikis merupakan kasus yang paling menyita perhatian. Hal ini dikarenakan jumlah korban kekerasan psikis dan fisik pada anak termasuk tinggi dibandingkan jenis kasus lainnya.

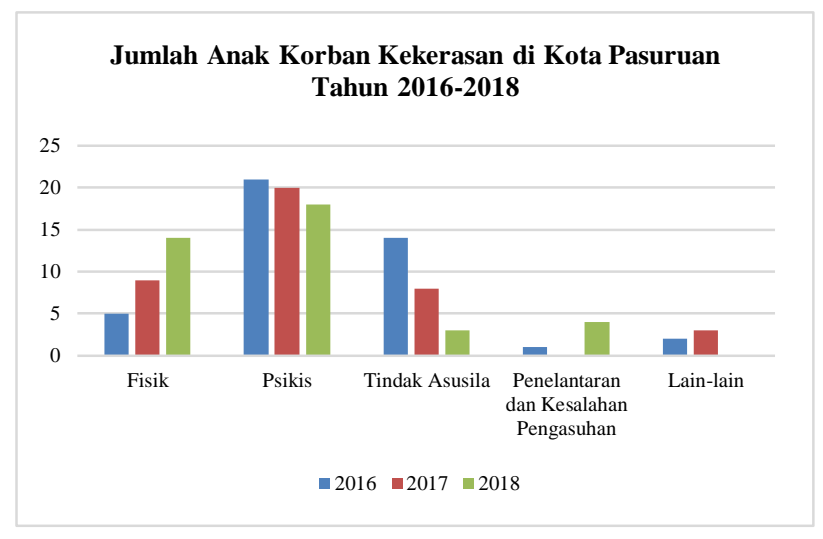

Gambar 1. Jumlah Anak Korban Kekerasan di Kota Pasuruan Tahun 2016-2018

Berdasarkan Gambar 1. di atas dijelaskan bahwa korban kekerasan psikis memiliki rata-rata paling tinggi. Disusul dengan korban kekerasan secara fisik, tindak asusila, penelantaran dan kesalahan pengasuhan beserta lainnya seperti perebutan hak asuh anak. Dalam hal ini tampak bahwa akumulasi anak korban kekerasan berhasil ditekan sejak tiga tahun terakhir. Pada tahun 2017 menurun sejumlah $0.025 \%$ dan tahun 2018 sebanyak 1\% dari tahun 2016. Demikian juga apabila ditelusuri dari akumulasi kasus di tahun 2018 berhasil turun menjadi 24 kasus dari 35 kasus yang terjadi pada tahun 2017. Hal ini dilatarbelakangi oleh adanya dukungan upaya pencegahan dan penanganan yang dilakukan. Kondisi ini sejalan dengan paparan Agustin et al. (2018) bahwa lebih dari 50\% anak mengalami kekerasan secara psikis dan fisik. Di dalam pendampingan anak berikut, kekerasan fisik tidak dapat dipisahkan secara psikis mengingat 
keduanya saling berpengaruh antar satu sama lain.

\section{Upaya Preventif pada Kasus Kekerasan Anak}

Adapun upaya preventif atau pencegahan yang dilakukan oleh Kota Pasuruan melalui DP3AKB dan P2TP2A selaku lembaga pemerhati anak yang aktif dari pemerintahan serta dari non-pemerintahan yakni LPA adalah sebagai berikut.

\section{Peningkatan Keterampilan Pengasuhan}

Upaya preventif yang pertama untuk mengantisipasi dan mengurangi faktor terjadinya kekerasan anak dilakukan melalui peningkatan keterampilan pengasuhan. Kota Pasuruan mengupayakan hal ini melalui kegiatan sosialisasi kepada para orangtua. Keterampilan pengasuhan tersebut diselenggarakan melalui kerja sama dengan pihak sekolah yang mendatangkan wali murid secara rutin di setiap semester. Selain itu juga dilakukan melalui kegiatan di organisasi atau komunitas tertentu yang melibatkan partisipasi orangtua. Upaya ini dilakukan kepada orangtua dan sekolah, karena orangtua sebagai lingkungan utama dan sekolah selaku lingkungan kedua anak. Dengan demikian diharapkan juga antara orangtua dan sekolah dapat menciptakan kondisi dan situasi ramah anak. Dengan demikian dapat mendukung perkembangan anak dengan optimal. Dalam pelaksanaan kegiatan ini, Kota Pasuruan juga menyediakan fasilitator terlatih yang selama ini juga berperan sebagai untuk melangsungkan kelancaran kegiatan peningkatan dan penguatan keterampilan pengasuhan.

\section{Penyediaan Layanan Ramah Anak untuk Korban Kekerasan}

Kota Pasuruan memiliki lembaga pemerhati anak meliputi P2TP2A (sektor pemerintahan) dan LPA (sektor non-pemerintahan) yang berada dalam satu atap di Sekretariat Kota Layak Anak di Jalan Balaikota No. 12 Pasuruan. Dalam menyediakan layanan ramah anak untuk korban kekerasan, P2TP2A dan LPA juga dibantu oleh beberapa satuan kerja perangkat daerah (SKPD) lain melalui jalinan kerja sama, seperti: Unit PPA Kepolisian, Dinas Kesehatan, RSUD dr. Soedarsono dan Puskesmas, Komisi Penanggulangan HIV/AIDS, akademisi, tokoh masyarakat, Lembaga Bantuan Hukum (LBH), Dinas Sosial, Dinas Pendidikan dan Kebudayaan (Dinas P\&K), Kejaksaan, dan Kementerian Agama. SKPD tersebut bekerja sesuai dengan tugas pokok dan fungsinya.

Adapun ragam layanan yang tersedia di lembaga P2TP2A selaku lembaga pemerintah yaitu pengaduan, konseling, medis, reintegrasi, home visit, medikolegal, psikososial, bantuan hukum, tokoh agama, dan rumah aman atau shelter. Sedangkan penyediaan layanan ramah anak dari lembaga non-pemerintah seperti LPA untuk korban kekerasan meliputi layanan pengaduan kekerasan, memberikan informasi dan bantuan pemulihan dan tindakan yang tepat.

\section{Diseminasi Informasi Perlindungan Anak}

Berdasarkan layanan yang sudah disediakan, lembaga pemerhati anak berupaya untuk melakukan diseminasi informasi perlindungan anak sebagai upaya preventif melalui sosialisasi ke lingkungan sekolah. Dalam praktiknya, sektor pemerintahan (DP3AKB dibantu P2TP2A) telah mengupayakan dengan baik melalui kegiatan rutinan yang dilaksanakan ke sekolah-sekolah setiap bulan atau maksimal setiap semester.

Tidak hanya itu, langkah diseminasi informasi juga dilakukan melalui portal sosial media resmi yang dimiliki. Namun, upaya diseminasi informasi perlindungan anak yang aktif dilakukan oleh sektor pemerintah ini bertentangan dengan langkah sektor nonpemerintahan (LPA). Dalam hal ini, LPA dinilai belum maksimal untuk menjalankan langkah ini. Permasalahan ini dapat terjadi dikarenakan LPA 
belum disertai dengan SDM yang memenuhi secara kuantitas dan mumpuni untuk melakukan penyebaran informasi.

Terkait poin berikut, penyebaran yang dilakukan tidak hanya mencakup informasi terkait layanan yang tersedia, melainkan juga terkait kebijakan yang berlaku. Artinya juga melakukan diseminasi terkait peran dan implementasi kebijakan tentang perlindungan anak yang diakomodir oleh negara dan pemerintah.

Bentuk perlindungan dan kebijakan di Kota Pasuruan berasal dari undang-undang secara nasional hingga peraturan yang diterbitkan oleh daerah, diantaranya: (a) Undang-undang Nomor 11 Tahun 2012 tentang Sistem Peradilan Anak; (b) Peraturan Daerah Provinsi Jawa Timur Nomor 2 Tahun 2014 tentang Sistem Penyelenggaraan Perlindungan Anak (terbit: 26 Februari 2014); (c) Peraturan Daerah Kota Pasuruan Nomor 11 Tahun 2013 tentang Perlindungan Perempuan dan Anak (terbit: 13 Mei 2013); (d) Peraturan Walikota Pasuruan Nomor 25 Tahun 2006 tentang Penyelenggaraan Korban Kekerasan dalam Rumah Tangga; dan (e) Peraturan Walikota Pasuruan Nomor 11 Tahun 2015 tentang Pusat Pelayanan Terpadu Perlindungan Perempuan dan Anak (PPT-PPA) Kota Pasuruan.

Dukungan peraturan dan kebijakan tentang perlindungan anak dan perempuan tersebut secara umum telah dipenuhi oleh Kota Pasuruan dalam rangka mengembangkan daerah layak anak. Dalam hal ini kebijakan perlindungan perempuan dan anak menjadi satu kesatuan, mengingat keduanya rentan mengalami kekerasan.

\section{Upaya Represif pada Kasus Kekerasan Anak}

Adapun upaya represif atau penanganan yang dilakukan oleh lembaga DP3AKB dibantu oleh P2TP2A selaku lembaga dari pemerintah serta dari non-pemerintah yakni LPA adalah sebagai berikut.

\section{Pengajuan Laporan Pengaduan Tindak Kekerasan}

Bentuk pendampingan awal sebagai upaya represif yakni pengajuan laporan pengaduan. Pengajuan laporan pengaduan dapat dilakukan oleh korban dan/atau pihak terdekat lainnya melalui datang langsung ke lokasi pengaduan yakni di P2TP2A atau LPA yang satu atap di Sekretariat Advokasi Kota Layak Anak Pasuruan. Selain dapat melaporkan secara langsung, pelaporan juga dapat ditempuh hotline yang tersedia pada kedua lembaga tersebut.

Pelapor dapat mengajukan laporan pengaduan terkait kasus yang dialami oleh anak dengan mengisi form. Form pelaporan memuat item pertanyaan terkait kronologi kasus dan layanan yang diperlukan. Berdasarkan laporan yang dicatat, maka dapat diidentifikasi dan ditangani sebagaimana layanan yang dikehendaki.

\section{Identifikasi Kasus sesuai Layanan yang dikehendaki}

Berdasarkan laporan pengaduan yang diterima, pihak lembaga pemerhati anak (P2TP2A dan/atau LPA) memberikan dukungan sosial secara instrumental berupa penerimaan laporan pengaduan dan melakukan identifikasi kasus sebagaimana pelayanannya guna menentukan langkah pendampingan selanjutnya. Layanan pendampingan dilakukan sebagai upaya penguatan self-esteem pada korban pasca kejadian kekerasan. Layanan yang tersedia di lembaga P2TP2A diantaranya layanan pengaduan, konseling, medis, reintegrasi, home visit, medikolegal, psikososial, bantuan hukum, tokoh agama, dan rumah aman atau shelter. Sedangkan penyediaan layanan di LPA untuk korban kekerasan berupa layanan pengaduan kekerasan, memberikan informasi dan bantuan pemulihan dan tindakan yang tepat.

Di sisi lain, layanan psikososial diperlukan untuk mengetahui kondisi korban. 
Pendampingan psikososial dilakukan melalui metode terapi sembari bermain untuk mengelola emosi dan menghilangkan rasa trauma yang dialami. Layanan psikososial ditempuh melalui tes psikologi dengan menggambar. Tes psikologi dengan menggambar digunakan untuk mengetahui tingkat kepercayaan diri anak. Diyakini oleh pendamping anak bahwa jika gangguan yang diderita dapat terlihat dari cara korban menggambar, salah satunya apabila menggambar pohon yang terpotong dapat mengindikasikan adanya traumatis pada psikis korban. Hasil analisis psikososial yang telah dilakukan dapat digunakan sebagai bahan pelaksanaan tindak lanjut seperti upaya mediasi atau rujukan. Dalam hal ini, pendamping anak dari P2TP2A dan/atau LPA telah memberikan dukungan emosional, instrumental, dan informasional kepada korban.

\section{Upaya Penanganan dan Penyelesaian Kasus}

Tahap ini merupakan penyelesaian masalah dan pemberian akses dalam rangka memenuhi kebutuhan korban. Dalam hal ini terdapat pemberian dukungan sosial secara instrumental dan emosional. Pada tahap ini pihak-pihak yang terlibat berupaya untuk melaksanakan pendampingan sesuai dengan perannya.

Adanya kasus kekerasan yang terjadi pada anak perlu menjadi perhatian bersama, terutama bagi orangtua dan sekolah yang menjadi lingkungan anak. Upaya penanganan dan penyelesaian kasus dapat dilakukan melalui pendampingan bantuan hukum dan non hukum. Berdasarkan temuan penelitian, secara umum penyelesaian kasus kekerasan anak di Kota Pasuruan yang melibatkan anak sebagai korban dan/atau pelaku dilakukan melalui jalur non hukum melalui mediasi.

Mediasi merupakan langkah utama yang mengedepankan sistem kekeluargaan dan musyawarah. Dalam proses mediasi, pihak korban dan pelaku didampingi oleh pihak keluarga beserta pendamping anak dari P2TP2A dan/atau LPA mendiskusikan terkait kronologi kasus, hasil analisis psikososial, saran yang menjadi bahan pertimbangan kedua belah pihak, serta pengawasan secara berkala terhadap perkembangan korban hingga dirasa korban telah memiliki kecukupan kemampuan untuk bangkit dari masa traumatik yang dialami. Namun, hal ini tentu berbeda apabila pelaku tindak kekerasan tidak termasuk dalam kategori anak terlebih kasus yang dilakukan tergolong pada kasus tindak kekerasan berat dan tidak dapat ditempuh melalui jalur mediasi. Dengan demikian akan ditangani melalui jalur hukum dengan bantuan pihak kepolisian dan kejaksaan beserta pihak terkait lainnya untuk mendukung proses berjalanannya penyelesaian kasus.

\section{Monitoring dan Evaluasi}

Setelah pelaksanaan penanganan dan penyelesaian kasus, baik melalui jalur hukum maupun non hukum, langkah yang akan ditempuh berikutnya adalah mengupayakan monitoring dan evaluasi (monev). Monitoring adalah proses pengumpulan informasi secara kontinyu untuk koreksi pelaksanaan. Sedangkan evaluasi adalah langkah penilaian untuk mengontrol kegiatan agar sesuai dengan tujuan.

Dalam hal ini monev merupakan salah satu bentuk dukungan emosional yang dilakukan untuk mengetahui perkembangan kasus dan memastikan bahwa keputusan penyelesaian kasus tindak kekerasan antara kedua belah pihak (pelaku dan korban) yang diajukan merupakan solusi terbaik. Monev dapat berlangsung lama dari waktu penyelesaian kasus sebagaimana tingkat kekerasan yang dialami korban. Berdasarkan temuan penelitian, rata-rata waktu monev pada kasus kekerasan fisik dan psikis berlangsung tiga hingga dua belas bulan. Sedangkan kasus kekerasan akibat tindak asusila dapat berlangsung hingga beberapa tahun sejak saat proses pengajuan laporan tindak kekerasan, proses penyidikan sampai pada pelaksanaan putusan hakim. 


\section{PEMBAHASAN}

Berdasarkan hasil penelitian yang telah dipaparkan terkait gambaran kekerasan, rata-rata anak di Kota Pasuruan dinyatakan sebagai korban. Hal ini sesuai dengan ulasan Mulyana, Resnawaty, \& Basar (2018) yang menyatakan bahwa di dalam kehidupan sehari-hari anakanak rentan untuk menjadi korban kekerasan, selain kaum perempuan. Anak yang terlibat kekerasan, baik sebagai korban maupun pelaku perlu mendapatkan pendampingan. Hal ini senada dengan paparan Hendra (2018) bahwa adanya upaya pendampingan dalam rangka menegakan perlindungan anak harus dilakukan melalui penerapan keadilan tanpa diskriminasi, baik kepada anak sebagai korban maupun pelaku tindak kekerasan.

Dari ulasan terkait gambaran kekerasan tersebut, maka diperlukan strategi pendampingan. Adapun strategi pendampingan yang dilakukan oleh Kota Pasuruan dalam memenuhi hak-hak anak korban kekerasan dinilai sebagai upaya pencegahan (preventif) dan represif (penanganan).

Lima strategi pendampingan anak korban kekerasan yang diterapkan oleh Kota Pasuruan yakni mencakup: (1) sosialisasi penguatan pengasuhan kepada keluarga; (2) penyediaan pendamping anak secar terlatih; (3) penguatan dukungan peraturan dan kebijakan perlindungan anak; (4) penyediaan layanan ramah anak bagi korban kekerasan; serta (5) pemetaan kasus kekerasan pada anak.

Secara umum, lima strategi pendampingan anak korban kekerasan yang telah dilakukan oleh Kota Pasuruan selaku salah satu daerah yang berkomitmen untuk mewujudkan kota ramah anak tersebut mencakup layanan psikologis, medis, dan yuridis. Selain itu juga sesuai dengan strategies to prevent and respond to violence against children antara lain meliputi: supporting parents, caregivers and families, helping children and adolescents manage risk and challenges, changing attitudes and social norms that encourage violence and discrimination, promoting and providing support services for children, implementing laws and policies that protect children, and carrying out data collection and research (United Nations Children's Fund (UNICEF) (2014). Berikut penjelasan dari keseluruhan tersebut:

\section{Sosialisasi Penguatan Pengasuhan}

Strategi pertama untuk mengantisipasi dan mengurangi faktor terjadinya kekerasan anak melalui sosialisasi peningkatan dan penguatan keterampilan pengasuhan. Kota Pasuruan selaku salah satu daerah yang menerapkan strategi pengarusutamaan hak anak pun menggiatkan penyelenggaraan sosialisasi kepada para orangtua melalui kerja sama dengan pihak sekolah secara rutin. Bahkan, kegiatan sosialisasi juga digencarkan di beberapa organisasi atau komunitas tertentu yang melibatkan partisipasi orangtua (Raharjo, 2018).

Sosialisasi penguatan pengasuhan merupakan kiat strategis untuk meningkatkan dan memberikan pengetahuan kepada keluarga (orangtua dan pengasuh) yang menjadi lingkungan utama bagi anak. Keluarga adalah lingkungan pertama dan utama yang dapat mempengaruhi perkembangan anak. Hal ini didasarkan pada peran keluarga yang turut membentuk perilaku dan kepribadian anak di masa mendatang. Oleh karena itu, diperlukan adanya pendampingan dari keluarga agar senantiasa menciptakan dan membentuk iklim keluarga yang positif tanpa kekerasan terutama kepada anak (Martínez-Monteagudo dkk., 2019; Saputro \& Talan, 2017).

Dalam hal ini, penguatan pengasuhan melalui sosialisasi juga akan meningkatkan interaksi positif antara orangtua dan anak, termasuk penerapan disiplin anti kekerasan dalam pengasuhan pada anak. Di sisi lain, strategi ini juga dilakukan untuk mendukung penyediaan informasi, pendidikan, dan pengetahuan atau 
edukasi yang meningkatkan parenting skill. Tujuan strategi ini adalah untuk mencegah potensi perilaku kekerasan terhadap anak (Hasanah \& Raharjo, 2016; Sitoresmi \& Amanah, 2012).

\section{Penyediaan Pendamping Anak secara Terlatih}

Strategi kedua yaitu penyediaan pendamping anak secara terlatih. Dalam hal ini, baik dari P2TP2A maupun LPA juga menyediakan tenaga pendamping anak. Tenaga pendamping anak di sini dimaksudkan sebagai fasilitator yang membantu anak untuk mencegah atau bahkan mengatasi dan mengelola risiko kekerasan, sehingga mengurangi terjadinya kekerasan. Fasilitator disebut juga sebagai agen perubahan atau pelaksana pemberdayaan masyarakat yang bertugas mendukung klien untuk menangani tekanan situasional yang dihadapinya melalui penyediaan fasilitas berupa layanan atau jasa serta kebijakan untuk meningkatkan kapasitasnya (Martsiswati \& Suryono, 2014; Rahma dkk., 2021).

Pendamping anak korban kekerasan ini telah mendapat serangkaian pengalaman pembinaan dan pendidikan serta pelatihan yang difasilitasi oleh D3AKB selaku leading sector pemenuhan hak anak. Dalam hal ini pendamping anak akan membekali anak dari tindak kekerasan melalui melatih untuk berpikir kritis, bertindak asertif, berani mengeluarkan pendapat dan menolak, memecahkan masalah secara kooperatif agar dapat melindungi dirinya sendiri dari tindak kekerasan.

Dalam mendampingi anak korban kekerasan, fasilitator anak juga melakukan pendampingan home visit sebagai langkah awal. Tujuan dari home visit ini adalah untuk mengetahui kondisi anak dan keluarga yang bersangkutan secara riil. Setelah melakukan observasi/investigasi dari home visit, pendamping melakukan pendampingan psikososial dan pendampingan sebagaimana layanan yang dibutuhkan oleh anak, baik layanan pendampingan secara hukum maupun non hukum.

Pendampingan psikososial dilakukan dengan metode terapi sembari bermain untuk mengelola emosi dan menghilangkan traumatik yang dialami korban. Selain itu, psikososial ditempuh melalui tes psikologi dengan menggambar. Tes psikologi dengan menggambar digunakan untuk mengetahui tingkat kepercayaan diri anak. Hal ini sesuai dengan pernyataan Muthmainnah (2014) bahwa anak korban kekerasan memerlukan pendampingan dari segi psikologis secara intensif seperti play therapy, expressive drawing, dan sebagainya.

\section{Penguatan Dukungan Peraturan dan Kebijakan Perlindungan Anak}

Strategi ini mencakup peran dan implementasi kebijakan sebagai penguat terkait peraturan perlindungan anak yang diakomodir oleh negara dan pemerintah. Dukungan peraturan dan kebijakan tentang perlindungan anak di Kota Pasuruan juga telah dipenuhi dalam rangka mengembangkan daerah layak anak. Chilmiati (2014) menegaskan bahwa peraturan dan kebijakan merupakan salah satu media yang mengakomodir upaya pencegahan, penanganan, dan perlindungan perempuan dan anak dari tindak kekerasan secara terus menerus.

Bentuk perlindungan dan kebijakan di Kota Pasuruan berasal dari undang-undang secara nasional hingga peraturan yang diterbitkan oleh daerah, diantaranya: (a) Undang-undang Nomor 11 Tahun 2012 tentang Sistem Peradilan Anak; (b) Peraturan Daerah Provinsi Jawa Timur Nomor 2 Tahun 2014 tentang Sistem Penyelenggaraan Perlindungan Anak (terbit: 26 Februari 2014); (c) Peraturan Daerah Kota Pasuruan Nomor 11 Tahun 2013 tentang Perlindungan Perempuan dan Anak (terbit: 13 Mei 2013); (d) Peraturan Walikota Pasuruan Nomor 25 Tahun 2006 tentang Penyelenggaraan Korban Kekerasan dalam Rumah Tangga; dan (e) Peraturan Walikota Pasuruan Nomor 11 
Tahun 2015 tentang Pusat Pelayanan Terpadu Perlindungan Perempuan dan Anak (PPT-PPA) Kota Pasuruan.

Dalam hal ini kebijakan perlindungan perempuan dan anak menjadi satu kesatuan, mengingat keduanya rentan mengalami kekerasan. Pernyataan tersebut diakui oleh Siregar (2015) bahwa perempuan dan anak sangat rentan mengalami kekerasan, di lingkup rumah tangga maupun ruang publik. Kelima peraturan dan kebijakan tersebut dijadikan sebagai acuan penyelenggaraan oleh Kota Pasuruan dalam melaksanakan perlindungan perempuan dan anak.

\section{Penyediaan Layanan Ramah Anak bagi Korban Kekerasan}

Strategi yang berkaitan dengan penyediaan layanan anak, seperti layanan pengaduan kekerasan, memberikan informasi dan bantuan pemulihan dan tindakan yang tepat. Kota Pasuruan memiliki lembaga pemerhati anak meliputi P2TP2A (sektor pemerintahan) dan LPA (sektor non-pemerintahan) yang berada dalam satu atap di Sekretariat Kota Layak Anak di Jalan Balaikota No. 12 Kota Pasuruan.

Selain itu dibantu oleh beberapa satuan kerja perangkat daerah (SKPD) lain melalui jalinan kerja sama, seperti: Unit PPA Kepolisian, Dinas Kesehatan, RSUD dr. Soedarsono dan Puskesmas, Komisi Penanggulangan HIV/AIDS, akademisi, tokoh masyarakat, Lembaga Bantuan Hukum (LBH), Dinas Sosial, shelter atau rumah aman di P2TP2A, Dinas Pendidikan dan Kebudayaan (Dinas P\&K), Kejaksaan, dan Kementerian Agama. SKPD tersebut bekerja sesuai dengan tugas pokok dan fungsinya. Dalam hal ini, pelaksanaan pengarusutamaan hak anak tidak hanya mengintegrasikan komitmen dan sumber daya pemerintah, melainkan juga dari masyarakat dan pihak lain secara menyeluruh, terencana, dan berkelanjutan dalam program dan kegiatan pemenuhan hak anak (Saleh dkk., 2020).
Dalam praktiknya, sektor pemerintahan telah mengupayakan dengan baik. Namun, hal ini bertentangan dengan sektor non-pemerintahan seperti LPA yang belum maksimal dalam pendampingan sehingga koordinasi di antara kedua sektor perlu ditingkatkan. Kondisi ini ditandai dengan tidak adanya aktivitas yang terlihat di kantor LPA selaku salah satu lembaga perlindungan anak saat pelaksanaan pendampingan. Di sisi lain lembaga nonpemerintahan juga belum disertai dengan SDM yang memenuhi. Adapun layanan yang disediakan untuk pendampingan anak korban kekerasan yakni yaitu pengaduan, konseling, medis, reintegrasi, home visit, medikolegal, psikososial, bantuan hukum, tokoh agama, dan rumah aman atau shelter.

Hal ini sebagaimana pendapat (Bakar, 2017) bahwa P2TP2A adalah pusat pelayanan bagi masyarakat yang terintegrasi dalam upaya pemberdayaan perempuan dalam bidang pembangunan serta perlindungan perempuan dan anak. Pusat pelayanan yang dibentuk oleh pemerintah berbasis masyarakat tersebut diharapkan dapat melindungi perempuan dan anak dari berbagai diskriminasi dan tindak kekerasan yang terjadi. Sedangkan pelayanan terpadu artinya serangkaian kegiatan yang dilakukan sebagai upaya perlindungan perlindungan terhadap korban kekerasan, yang dilaksanakan secara bersama-sama oleh instansi atau lembaga terkait. Upaya ini dinilai sebagai satu kesatuan penyelenggaraan rehabilitasi kesehatan, rehabilitasi sosial, pemulangan, reintegrasi sosial dan bantuan hukum. Oleh karena itu, layanan pada P2TP2A dapat berupa: pusat rujukan, pusat konsultasi usaha, pusat konsultasi kesehatan reproduksi, pusat konsultasi hukum, pusat krisis terpadu (PKT), pusat pelayanan terpadu (PPT), pusat pemulihan trauma (trauma center), pusat penanganan krisis perempuan (women crisis center), pusat pelatihan, pusat informasi ilmu pengetahuan dan 
teknologi (PIPTEK), rumah aman (shelter), rumah singgah, atau bentuk lainnya.

\section{Pemetaan Kasus Kekerasan pada Anak}

Strategi ini mencakup pengumpulan dan sistem informasi untuk mengidentifikasi kelompok anak yang terlibat kasus kekerasan melalui pengoptimalan ketersediaan data tentang isu-isu kekerasan anak. Dalam hal ini Kota Pasuruan telah memetakan kekerasan anak berdasarkan jenis kekerasan, lokasi, jenis kelamin, usia, dan penanganan yang telah dilakukan di setiap tahunnya. Adanya data tersebut selanjutnya dilaporkan ke tingkat nasional oleh DP3AKB setelah melaksanakan rapat koordinasi.

Pemetaan kasus kekerasan pada anak tersebut juga membantu menggambarkan perkembangan kondisi daerah serta kebutuhan Kota Pasuruan sebagai kota layak anak yang berupaya untuk meminimalisir kasus kekerasan pada anak. Hal ini diperkuat oleh Bakar (2017) bahwa pemetaan secara mendalam perlu dilakukan untuk mengetahui sejauhmana kinerja serta komitmen dari pihak-pihak yang terlibat seperti pemerintah dan lembaga penyedia layanan perlindungan anak yang dibantu oleh masyarakat bahkan dunia usaha dalam memberikan program hingga fasilitas agar anak tetap memperoleh hak sebagaimana mestinya.

\section{SIMPULAN}

Berdasarkan penelitian yang dilaksanakan, dapat ditarik kesimpulan bahwa Kota Pasuruan berkomitmen untuk memenuhi hak anak sebagaimana predikat kota layak anak yang selama ini disematkan. Dalam hal ini, upaya tersebut dilakukan melalui penerapan lima strategi pendampingan pada anak korban kekerasan yang mencakup psikologis, medis, dan yuridis sebagai berikut: (1) sosialisasi penguatan pengasuhan kepada keluarga; (2) penyediaan pendamping anak secar terlatih; (3) penguatan dukungan peraturan dan kebijakan perlindungan anak; (4) penyediaan layanan ramah anak bagi korban kekerasan; dan (5) pemetaan kasus kekerasan pada anak.

Kota Pasuruan melalui lembaga yang bertugas seperti P2TP2A dan/atau LPA juga menyediakan layanan preventif yang mencakup: peningkatan keterampilan pengasuhan, penyediaan layanan ramah anak untuk korban kekerasan, dan diseminasi informasi perlindungan anak. Sedangkan layanan represif meliputi: pengajuan laporan pengaduan kekerasan, identifikasi kasus sesuai layanan, upaya penanganan dan penyelesaian kasus, serta monitoring dan evaluasi.

Upaya perlindungan terhadap anak korban kekerasan yang dilakukan oleh Kota Pasuruan sebagai salah satu wujud komitmen bersama dalam melaksanakan strategi pendampingan pada anak korban kekerasan sebagai upaya pemenuhan hak anak patut diapresiasi.

Saran terkait strategi pendampingan anak korban kekerasan diharapkan agar seluruh pihak yang terlibat, baik dari pihak pemerintahan dan non-pemerintahan saling memperkuat koordinasi. Dengan demikian tercipta sinergitas yang baik antara kedua belah pihak, sehingga pelaksanaan program menjadi lebih efektif dan tidak memberatkan salah satu pihak.

Secara akademik, hasil penelitian ini dapat memberikan kontribusi untuk menambah kajian ilmu tentang strategi pendampingan pada anak yang dibentuk dari konfigurasi antara keluarga, masyarakat beserta pemerintah dan negara.

\section{DAFTAR RUJUKAN}

Agustin, M., Saripah, I., \& Gustiana, A. D. (2018). Analisis Tipikal Kekerasan Pada Anak Dan Faktor Yang Melatarbelakanginya. JIV, 13(1), 1-10. https://doi.org/10.21009/JIV.1301.1

Bakar, H. A. (2017). Pemetaan Pusat Pelayanan Terpadu Pemberdayaan Perempuan dan Anak (P2TP2A) Provinsi Sumatera Barat. Kafa'ah: Journal of Gender 
Studies, $7(1)$ 107. https://doi.org/10.15548/jk.v7i1.168

Callaghan, J. E. M., Fellin, L. C., Mavrou, S., Alexander, J., \& Sixsmith, J. (2017). The Management of Disclosure in Children's Accounts of Domestic Violence: Practices of Telling and Not Telling. Journal of Child and Family Studies, 26(12), 3370-3387. https://doi.org/10.1007/s10826-0170832-3

Chilmiati, N. (2014). Kebijakan Advokasi Terhadap Perempuan Dan Anak Berbasis Perlindungan Korban Kekerasan. Law Reform, 9(2), 110. https://doi.org/10.14710/lr.v9i2.12449

Graha, A. N. (2009). Pengembangan Masyarakat Pembangunan Melalui Pendampingan Sosial Dalam Konsep Pemberdayaan Di Bidang Ekonomi. Jurnal Ekonomi Modernisasi, 5(2), 117-126.

Hasanah, U., \& Raharjo, S. T. (2016). PENANGANAN KEKERASAN ANAK BERBASIS MASYARAKAT. Share: Social Work Journal, 6(1). https://doi.org/10.24198/share.v6i1.131 50

Hendra, R. (2018). PENERAPAN KEADILAN RESTORATIF DI INDONESIA BAGI ANAK YANG SEDANG BERHADAPAN HUKUM. Jurnal Surya Kencana Dua: Dinamika Masalah Hukum dan Keadilan, 5(2), 19.

Kementerian Pemberdayaan Perempuan dan Perlindungan Anak Republik Indonesia. (2017). Statistik Gender TematikMengakhiri Kekerasan Terhadap Perempuan dan Anak di Indonesia. KPP\&PA.

Lourenco, L. M., Baptista, M. N., Senra, L. X., Adriana A., A., Basilio, C., \& Bhona, F. M. de C. (2013). Consequences of Exposure to Domestic Violence for Children: A Systematic Review of the
Literature. Paidéia (Ribeirão Preto), 23(55), 263-271. https://doi.org/10.1590/1982-

43272355201314

Martínez-Monteagudo, M. C., Delgado, B., Inglés, C. J., \& García-Fernández, J. M. (2019). Cyberbullying in the university setting. Relationship with family environment and emotional intelligence. Computers in Human Behavior, 91, 220 225.

https://doi.org/10.1016/j.chb.2018.10.00 2

Martsiswati, E., \& Suryono, Y. (2014). Peran Orang Tua Dan Pendidik Dalam Menerapkan Perilaku Disiplin Terhadap Anak Usia Dini. Jurnal Pendidikan dan Pemberdayaan Masyarakat, 1(2), 187. https://doi.org/10.21831/jppm.v1i2.2688

Mulyana, N., Resnawaty, R., \& Basar, G. G. K. (2018). Penanganan Anak Korban Kekerasan. 13, 13.

Muthmainnah. (2014). Membekali Anak dengan Keterampilan Melindungi Diri. Jurnal Pendidikan Anak, 3(1), 443-451.

Raharjo, K. M. (2018). Pemberdayaan Anak Jalanan Sebagai Upaya Penyadaran Belajar Melalui Pendidikan Kesetaraan Di Kota Samarinda. Jurnal Pendidikan Nonformal, 13(2), 7.

Rahma, R. A., Sucipto, \& Widyaswari, M. (2021). The Role of Social Workers in Empowering Socioeconomic Women in the Time of Covid-19 Pandemic: 5th International Conference on Arts Language and Culture (ICALC 2020), Surakarta, Indonesia. https://doi.org/10.2991/assehr.k.210226. 048

Saleh, A., Evendia, M., \& Riananda, M. (2020). Pemetaan Kebutuhan Produk Hukum Daerah dalam Rangka Mewujudkan Kabupaten/Kota Layak Anak. Kanun Jurnal Ilmu Hukum, 22(1), 1-24. 
https://doi.org/10.24815/kanun.v22i1.15

694

Saputro, H., \& Talan, Y. O. (2017). Pengaruh Lingkungan Keluarga Terhadap Perkembangan Psikososial Pada Anak Prasekolah. Journal of Nursing Practice, 1(1), 8.

Siregar, H. (2015). Bentuk-Bentuk Kekerasan yang Dialami Perempuan Warga Komplek Dinas Peternakan Provinsi Sumatera Utara. 14(1), 10.

Sitoresmi, Rr. N., \& Amanah, S. (2012). Pendampingan Perempuan Korban Tindak Kekerasan Oleh Pusat Pelayanan Terpadu Pemberdayaan Perempuan Dan Anak (P2TP2A). Sodality: Jurnal Sosiologi Pedesaan, 6(3), 12.

Undang-undang Nomor 35 Tahun 2014 tentang Perlindungan Anak.

United Nations Children's Fund (UNICEF). (2014). Ending Violence Against Children: Six Strategies for Action. UNICEF. 